
\title{
Research S Surare \\ Level of SARS-CoV-2 IgG antibodies after two doses CoronaVac vaccine: Primarily report
}

\section{Umut Binay ( $\nabla$ devrimbinay@hotmail.com )}

Erzincan Binali Yildirim University

\section{Faruk Karakecili}

Erzincan Binali Yildirim University

Orcun Barkay

Erzincan Binali Yildirim University

\section{Ozlem Gul}

Erzincan Binali Yildirim University

\section{Cuma Mertoglu}

Erzincan Binali Yildirim University

\section{Research Article}

Keywords: COVID-19, CoronaVac vaccine, SARS-CoV-2 IgG

Posted Date: April 12th, 2021

DOI: https://doi.org/10.21203/rs.3.rs-388073/v2

License: (c) (1) This work is licensed under a Creative Commons Attribution 4.0 International License. Read Full License 


\section{Abstract}

Background: It is necessary to use an effective vaccine to end the COVID-19 pandemic.CoronaVac vaccine is used in our country and we aimed to examine the level of antibody development after theseconddose.

Methods:This is a retrospective, cross-sectional research. The dataof the people, who applied to a university hospital between January and March 2021, were analyzed. Those who had SARS-CoV-2 IgG and IgMmeasurement in the previous two weeks before the CoronoVac vaccine, and those who were both found negative and who had SARS-CoV-2 IgG and IgM measurement after the seconddose of CoronaVac vaccine were included in the research. SARS-CoV-2 IgG/lgM were measured by VIDAS $\AA$ (BioMérieux, Marcy-l'Etoile, France) device for the detection of spike protein specific lgG/lgM of SARS-CoV-2 in human serum with ELFA (Enzyme Linked Fluorescent Assay) technique.

Results: 75 people were included in thisresearch. It was found that the individuals had SARS-CoV-2 IgG and IgM measurements between 14 and 21 days after the first dose of CoronaVac vaccine.It was observed that $12 \%(n=9)$ of the cases had a history of COVID-19.The rate of positivity for SARS CoV-2 IgG level after vaccination was $100 \%$.

Conclusions: It can be said that two doses of CoronaVac vaccine create an effective humoral immunity.

\section{Introduction}

A new strain of coronavirus was identified as the cause of a series of pneumonia cases in Wuhan, a city in Hubei province of China, at the end of 2019. The virus spread rapidly all over the world, causing a global pandemic, and the pandemic still continues. The name of the virus was defined as severe acute respiratory syndrome coronavirus 2 (SARS-CoV-2), and the World Health Organization (WHO) defined the disease as COVID-19, which stands for 2019 coronavirus disease,in February 2020(1).

To prevent SARS-CoV-2 infection,vaccine developement is considered as the most promising approach to control the pandemic andis followed by the whole world. By the end of 2020 , several vaccines were ready to use in different parts of the world with emergency approval (2).

CoronaVac 600 SU/0.5 ml (Sinovac Life Sciences, Beijing, China) vaccine, which is an inactive COVID-19 vaccine has been usedafter obtaining emergency approval in our country (3). As of January 14, 2021, vaccination has been initiated for our population starting with healthcare workers (4). The vaccine, which was administered intramuscularly as 2 doses in 28 days, was shown to be safe and immunogenic in Phase 1 and 2 trials (5).

In this research, it was aimed to evaluate the effectiveness of the CoronaVac vaccine aftertwodosesby examining the results of people who had SARS-CoV-2 immunoglobulin $\mathrm{G}(\mathrm{IgG})$ and immunoglobulin $\mathrm{M}$ (IgM) measurements in our hospital. 


\section{Materials And Methods}

This is a retrospective, cross-sectional research and was conducted with the informed consent of all participants.Ministry of Health and Erzincan Binali Yıldırım University (EBYU)ethics committee approvals have been obtained ( Date: 22.03.2021 and Decision no: 05/27).All methods were performed in accordance with the relevant guidelines and regulations.

The dataof the people who applied to the COVID-19 Antibody Polyclinic of EBYU Mengücek Gazi Training and Research Hospital between January and March 2021 wereretrospectively analyzed; the people who met the inclusion criteria were detected and their data were collected. Accordingly, those who had SARSCoV-2 IgG and IgM measurement in the previous two weeks before the CoronoVac vaccine, and those who were both found negative and who had SARS-CoV-2 IgG and IgM measurement after the seconddose of CoronaVac vaccine were included in the research. People who had negative antibody results before vaccination but were not vaccinated and those who did not have a measurement of antibodylevels after vaccination were not included in the research. The demographic data of the individuals (age, gender, presence of comorbidities, medications, etc.), whether they had COVID-19 and how long ago they had COVID-19 were evaluated. For the participants having a history of COVID-19; complete blood count (CBC), serum ferritin, C-reactive protein (CRP) and D-dimer levels' results were also collected.

75 people were included in thisresearch. It was found that the individuals had SARS-CoV-2 IgG and IgM measurements between 14 and 21 days after the seconddose of CoronaVac vaccine.

SARS-CoV-2 IgG and IgM measurements;

1. SARS-CoV-2 IgG was measured by VIDAS $®$ (BioMérieux, Marcy-l'Etoile, France) device for the detection of spike protein specific IgG of SARS-CoV-2 in human serum with ELFA (Enzyme Linked Fluorescent Assay) technique.

2. SARS-CoV-2 IgM was measured by VIDAS $®$ (BioMérieux, Marcy-l'Etoile, France) device for the detection of spike protein specific IgM of SARS-CoV-2 in human serum with ELFA (Enzyme Linked Fluorescent Assay) technique.

\section{Interpretation of the results}

The interpretation of the results according to the test value is as: $<1,00$ (negative) and $>1.00$ (positive) (7).

CBC was measured by the Sysmex XN-1000 Hematology System (SysmexCorporation, Kobe, Japan) automated blood counter. Serum ferritin level was measured by chemiluminescence immunoassay (Centaur XP, Siemens Healthcare, Germany). CRP was measured by the BN ${ }^{\mathrm{TM}}$ II System device by the 
nepholometric method (Siemens, Munich, Germany). D-dimer level was measured from whole blood by the AQT90 flex Radiometer ${ }^{\circledR}$ (Bronshoj, Denmark) device.

\section{Statistical Analysis}

NCSS (NumberCruncher Statistical System) program was used for statistical analysis. Descriptive statistical methods (mean, standard deviation, median, frequency, percentage, minimum, maximum) were used while evaluating the study data. The suitability of quantitative datawith normal distribution was tested by Shapiro-Wilk, Kolmogorov-Smirnovtests and graphical analysis. Mann-Whitney U test was used for the comparison of quantitative variables that did not show normal distribution between two groups. Spearman correlation analysis was used to evaluate the relationships between quantitative variables. Statistical significance was accepted as $p<0.05$.

\section{Results}

The research was carried out in EBYU Mengücek Gazi Training and Research Hospital between the dates of $01.01 .2021-31.03 .2021 .50 .7 \%(n=38)$ of the cases were female and $49.3 \%(n=37)$ were male. The ages of the cases ranged from 23 to 74 , with a mean age of $38.41 \pm 8.50$.

It was observed that $12 \%(n=9)$ of the cases had a history of COVID-19. The duration of having COVID-19 ranges from 2 to 8 months before the vaccination, with an average of $4.28 \pm 2.28$ months.

In all cases $(n=75)$, it was observed that SARS CoV-2 IgG level was positive after 2 doses of vaccine. The IgG levels of the cases ranged from 1.22 to 45 , and the mean value was found to be $10.81 \pm 8.04$ (Table 1).SARS CoV-2 IgM levels of the cases were found to be negative. 
Table 1

Distribution of Descriptive Features

\begin{tabular}{|c|c|c|}
\hline Age (year) & Min-Max (Median) & $23-74(39)$ \\
\hline & Mean $\pm S D$ & $38.41 \pm 8.50$ \\
\hline \multirow[t]{2}{*}{ Gender } & Female & $38(\% 50.7)$ \\
\hline & Male & $37(\% 49.3)$ \\
\hline \multirow[t]{2}{*}{ History of COVID-19 } & No & $66(\% 88)$ \\
\hline & Yes & $9(\% 12)$ \\
\hline \multirow[t]{2}{*}{ The duration of having COVID-19(month) } & Min-Max (Median) & $2-8$ ay (3 ay) \\
\hline & Mean $\pm S D$ & $4.28 \pm 2.28$ \\
\hline \multicolumn{3}{|c|}{ SARS-CoV-2 IgG Result after two doses vaccine } \\
\hline & Positive & $75(\% 100)$ \\
\hline & Min-Max (Median) & $1.22-45(10.33)$ \\
\hline & Mean $\pm S D$ & $10.81 \pm 8.04$ \\
\hline
\end{tabular}

The leukocyte counts of people having a history of COVID-19 during the disease period varied between 4.300 and $9.800 / \mathrm{mm}^{3}$, with an average of $7055.56 \pm 1636.39 / \mathrm{mm}^{3}$; their platelet counts between 197.000 and $342.000 / \mu \mathrm{L}$, with an average of $248000.00 \pm 49272.20 / \mu \mathrm{L}$; hemoglobin levels varied between 11.1 and $17.3 \mathrm{~g} / \mathrm{dL}$, with an average of $14.70 \pm 1.95 \mathrm{~g} / \mathrm{dL}$; lymphocyte counts varied between 510 and $3880 / \mu \mathrm{L}$, with an average of $1897.78 \pm 1066.84 / \mu \mathrm{L}$; neutrophil counts variedbetween 1650 and $6220 / \mu \mathrm{L}$, with an average of $4213.33 \pm 1481.07 / \mu \mathrm{L}$; serum CRP levels varied between 3 and $23 \mathrm{mg} / \mathrm{L}$, with an average of $6.63 \pm 7.33 \mathrm{mg} / \mathrm{L}$; D-Dimer levels varied between 128 and $690 \mu \mathrm{g} / \mathrm{L}$, with an average of $345.22 \pm 175.68 \mu \mathrm{g} /$ Land ferritin levels ranged from 6 to $150 \mathrm{ng} / \mathrm{mL}$, with an average of $70.44 \pm 48.47$ $\mathrm{ng} / \mathrm{mL}$ (Table 2). 
Table 2

Distribution of Laboratory Results of Cases with History of COVID-19

\begin{tabular}{|c|c|c|}
\hline \multirow[t]{2}{*}{ Leukocyte Counts $\left(/ \mathrm{mm}^{3}\right)$} & Min-Max (Median) & $4300-9800(6800)$ \\
\hline & Mean $\pm S D$ & $7055.56 \pm 1636.39$ \\
\hline \multirow[t]{2}{*}{ Platelet Counts $(/ \mu \mathrm{L})$} & Min-Max (Median) & $197000-342000(226000)$ \\
\hline & Mean $\pm S D$ & $248000.00 \pm 49272.20$ \\
\hline \multirow[t]{2}{*}{ Hemoglobin levels(g/dL) } & Min-Max (Median) & $11,1-17.3(15.1)$ \\
\hline & Mean $\pm S D$ & $14.70 \pm 1.95$ \\
\hline \multirow[t]{2}{*}{ Lymphocyte Counts $(/ \mu \mathrm{L})$} & Min-Max (Median) & $510-3880(1640)$ \\
\hline & Mean $\pm S D$ & $1897.78 \pm 1066.84$ \\
\hline \multirow[t]{2}{*}{ Neutrophil Counts $(/ \mu L)$} & Min-Max (Median) & $1650-6220(4610)$ \\
\hline & Mean $\pm S D$ & $4213.33 \pm 1481.07$ \\
\hline \multirow[t]{2}{*}{ CRP Levels( 0-5 mg/L) } & Min-Max (Median) & $3-23(3)$ \\
\hline & Mean $\pm S D$ & $6.63 \pm 7.33$ \\
\hline \multirow[t]{2}{*}{ D-Dimer Levels( $(\mu \mathrm{g} / \mathrm{L})$} & Min-Max (Median) & $128-690(342)$ \\
\hline & Mean $\pm S D$ & $345.22 \pm 175.68$ \\
\hline \multirow[t]{2}{*}{ Ferritin Levels(ng/mL) } & Min-Max (Median) & $6-150(50)$ \\
\hline & Mean $\pm S D$ & $70.44 \pm 48.47$ \\
\hline
\end{tabular}

The age and gender distributions of the cases according to the SARS CoV-2 IgG levels after vaccination did not show a statistically significant difference ( $p>0.05)$.According to the presence of Covid-19 history, no statistically significant difference was found between the post-vaccination SARS CoV-2 IgG levels of the cases $(p>0.05)$ (Table 3$)$. 
Table 3

Comparisons by Post Vaccine SARS CoV-2 IgG Levels

\begin{tabular}{|c|c|c|c|c|}
\hline & & \multicolumn{2}{|c|}{$\begin{array}{l}\text { Post Vaccine SARS CoV-2 } \\
\text { IgG Levels }\end{array}$} & \multirow[b]{2}{*}{$\mathbf{P}$} \\
\hline & & $\begin{array}{l}\text { Min-Max } \\
\text { (Median) }\end{array}$ & $\begin{array}{l}\text { Mean } \pm \\
\text { SD }\end{array}$ & \\
\hline \multirow[t]{2}{*}{ Gender } & Female $(n=38)$ & $1.3-45(9.6)$ & $\begin{array}{l}10.86 \pm \\
8.61\end{array}$ & ${ }^{\dagger} 0.878$ \\
\hline & Male $(n=37)$ & $1.2-30(10.6)$ & $\begin{array}{l}10.76 \pm \\
7.54\end{array}$ & \\
\hline \multirow[t]{3}{*}{ History of COVID-19 } & No $(n=66)$ & $1.3-45(10.4)$ & $\begin{array}{l}10.90 \pm \\
7.96\end{array}$ & ${ }^{\dagger} 0.648$ \\
\hline & Yes $(n=9)$ & $1.2-30(6.5)$ & $\begin{array}{l}10.13 \pm \\
9.08\end{array}$ & \\
\hline & & $r$ & $\mathrm{P}$ & \\
\hline Age & & $-0,053$ & 0,653 & \\
\hline
\end{tabular}

\section{Discussion}

One of the important ways to control the COVID-19 pandemic is to producean effective vaccine. Currently, various vaccines generatedby different methods are being used all over the world with emergency use approval (2). When the effectiveness of vaccines in use are examined; Pfizer / BioNTech, Gamaleya, Moderna and AstraZeneca announced the vaccine efficiency as 95\%, 92\%, 94.5\%, 70\%, respectively $(8,9$, $10)$. For the CoronaVac vaccine, efficacy statements have been received from different countries at different rates $(50.4 \%, 65.3,78,91.25)$, and these data have not been published yet $(11,12)$.

Recently, different SARS-CoV-2 variants have brought some reservations about the effectiveness of vaccines. It is thought that the immunity created by the vaccine against some variants may not be effective. It is stated that especially mRNA vaccines will need to be revised (13-15). However, Iversen and Bavari stated that compared to vaccines targeting only spike protein, inactivated vaccines would provide additional benefit as they target many SARS-CoV-2 proteins (16). Another drawback regarding vaccines is whether or not a booster dose will be required. In a study conducted with healthcare workers infected with SARS-CoV-2, it was shown that neutralizing antibody levels decreased over time. Therefore, it has been suggested that booster vaccination may be required periodically (17).

SARS-CoV-2 vaccines have been developed very rapidly and because of this they have brought some concerns in terms of long-term side effect profile. Anaphylaxis is one of the important life-threatening side effects and there are concerns that it may be more likely to be seen in mRNA vaccines $(12,18-20)$. 
CoronaVac 600 SU/0.5 ml (Sinovac Life Sciences, Beijing, China) vaccine, which is an inactive COVID-19 vaccine isbeing used after obtaining emergency use approval in our country (3). The vaccine is administered intramuscularly in 2 doses, 28 days apart. When the literature was examined, it was found that real-life data on CoronaVac vaccine was not shared before. The data in our research is the first reallife data of CoronoVac vaccine and is important in this regard.

Another issue is how protective the antibodies against SARS-CoV-2 are. In the study conducted by Lumley et al., itwas shown that the incidence of COVID-19 in healthcare workers with SARS-CoV-2 IgG positivity was significantly lower. Antibodies against spike protein and / or nucleocapsid have been shown to be protective (21). In the study conducted by Borgonovo et al.,itwas shown that IgG formed against spike protein continued for 7 months and symptomatic COVID-19 infection did not develop in these people (22). In another study by Zhang et al.,itwas shown that B lymphocyte response developed in the first 14 days after a single dose of CoronaVac vaccine, but $T$ lymphocyte response developed after the second dose (23). When the data of our study were examined, the rate of antibody formation after the second dose of vaccination in all individuals was found to be $100 \%$. These data show that the CoronaVac vaccine is effective after two doses.

There are some limitations in our study.One of them is being conducted in a single center with a small number of people. In addition, cellular immunity was not evaluated and protection was measured only by the antibody level. In this context, multi-centered studies consisting of larger groups evaluating antibody and cellular immune response level after first and second dose of vaccination are needed.

In conclusion, antibody development level was found to be $100 \%$ after two doses of CoronaVac vaccine. It can be said that two doses of CoronaVac vaccine create an effective humoral immunity. Therefore, two doses of CoronaVac vaccine application is effective against SARS-CoV-2.

\section{Declarations}

\section{Acknowledgments}

There is no special thanks.

\section{Declaration of Interest Statement}

The authors have no conflicts of interest.

\section{References}

1. -World HealthOrganization. Director-General'sremarks at themediabriefing on 2019-nCoV on 11 February 2020. http://www.who.int/dg/speeches/detail/who-director-general-s-remarks-at-the-mediabriefing-on-2019-ncov-on-11-february-2020 (Accessed on 20.02.2021) 
2. -World HealthOrganization. Draftlandscape of COVID-19 candidatevaccines.

https://www.who.int/publications/m/item/draft-landscape-of-covid-19-candidate-vaccines (Accessed on20.02.2021)

3. -https://www.titck.gov.tr/haber/kamuoyunun-dikkatine-13012021185623 (Accessed on 20.02.2021)

4. -https://www.bbc.com/turkce/haberler-turkiye-55657237 (Accessed on 21.02.2021)

5. Zhang, Y.,Zeng, G., Pan, H., Li, C., Hu, Y., Chu, K., ... Zhu, F. (2020). Safety, tolerability,andimmunogenicity of an inactivated SARS-CoV-2 vaccine in healthyadultsaged 18-59 years: a randomised, double-blind, placebo-controlled, phase $1 / 2$ clinicaltrial.

TheLancetInfectiousDiseases.

6. Wu, Z., Hu, Y., Xu, M., Chen, Z., Yang, W., Jiang, Z., ... Yin, W. (2021). Safety, tolerability,and immunogenicity of an inactivated SARS-CoV-2 vaccine (CoronaVac) in healthy adults aged 60 years and older: a randomised, double-blind, placebo-controlled, phase 1/2 clinical trial. The Lancet Infectious Diseases.

7. Renard, N., Daniel, S., Cayet, N., Pecquet, M., Raymond, F., Pons, S., ... Berthier,F. (2021). Performance characteristics of the VIDAS ${ }^{\circledR}$ SARS-COV-2 IgM and IgG serological assays. Journal of clinical microbiology.

8. Polack, F. P., Thomas, S. J., Kitchin, N., Absalon, J., Gurtman, A., Lockhart, S.,... Gruber, W. C. (2020). Safety and efficacy of the BNT162b2 mRNA Covid-19 vaccine. New England Journal of Medicine, 383(27), 2603-2615.

9. Voysey, M., Clemens, S. A. C., Madhi, S. A., Weckx, L. Y., Folegatti, P. M., Aley,P. K., ... Bijker, E. (2021). Safety and efficacy of the ChAdOx1 nCoV-19 vaccine (AZD1222)against SARS-CoV-2: an interim analysis of four randomised controlled trials in Brazil,South Africa, and the UK. The Lancet, 397(10269), 99-111.

10. -Knoll, M. D. \& Wonodi, C. Oxford-AstraZeneca COVID-19 vaccine efficacy. The Lancet. 397 (10269), 72-74 (2021).

11. Sinovac, B. B. C. Brazil results show Chinese vaccine $50.4 \%$ effective. https://www.bbc.com/news/world-latin-america-55642648 (Accessed on 22.02.2020).

12. -Mallapaty, S. China COVID vaccine reports mixed results - what does that mean for the pandemic? Nature. 2021 Jan 15. doi: 10.1038/d41586-021-00094-z. Epub ahead of print. PMID: 33452510.

13. -Moore, J. P. \& Offit, P. A. SARS-CoV-2 vaccines and the growing threat of viral variants. JAMA. 325 (9), 821-822 (2021).

14. Garcia-Beltran, W. F., Lam, E. C., Denis, K. S., Nitido, A. D., Garcia, Z. H., Hauser,B. M., ... Balazs, A. B. (2021). Multiple SARS-CoV-2 variants escape neutralization by vaccine-induced humoral immunity. Cell.

15. Xie, X., Liu, Y., Liu, J., Zhang, X., Zou, J., Fontes-Garfias, C. R., ... Shi, P. Y.(2021). Neutralization of SARS-CoV-2 spike 69/70 deletion, E484K and N501Y variants by BNT162b2 vaccine-elicited sera. Nature Medicine, 1-2. 
16. -Iversen, P. L. \& Bavari, S. (2021). Inactivated COVID-19 vaccines to make a global impact. The Lancet Infectious Diseases.

17. Marot, S., Malet, I., Leducq, V., Zafilaza, K., Sterlin, D., Planas, D., ... Marcelin,A. G. (2021). Rapid decline of neutralizing antibodies against SARS-CoV-2 among infected healthcare workers. Nature communications, 12(1), 1-7.

18. -Castells, M. C. \& Phillips, E. J. Maintaining safety with SARS-CoV-2 vaccines. New England Journal of Medicine. 384 (7), 643-649 (2021).

19. -CDC COVID-19 Response Team, \& Food and Drug Administration (2021). Allergic Reactions Including Anaphylaxis After Receipt of the First Dose of Pfizer-BioNTech COVID-19 Vaccine - United States, December 14-23, 2020. MMWR. Morbidity and mortality weekly report, 70(2), 46-51. https://doi.org/10.15585/mmwr.mm7002e1

20. -Zellweger, R. M., Wartel, T. A., Marks, F., Song, M. \& Kim, J. H. Vaccination against SARS-CoV-2 and disease enhancement-knowns and unknowns. Expert Review of Vaccines. 19 (8), 691-698 (2020).

21. Lumley, S. F., O’Donnell, D., Stoesser, N. E., Matthews, P. C., Howarth, A., Hatch,S. B., ... Eyre, D. W. (2020). Antibody status and incidence of SARS-CoV-2 infection in health care workers. New England Journal of Medicine.

22. -Borgonovo, F. et al. (2021). Is COVID-19 severity associated with anti-spike antibody duration? Data from the ARCOVID prospective observational study. The Journal of infection, S0163-4453(21)00048 - 7. Advance online publication. https://doi.org/10.1016/j.jinf.2021.01.023

23. Zhang, H., Hu, Y., Jiang, Z., Shi, N., Lin, H., Liu, Y., ... Xia, Q. (2021). Single-Cell Sequencing and Immune Function Assays of Peripheral Blood Samples Demonstrate Positive Responses of an Inactivated SARS-CoV-2 Vaccine. 